\title{
西藏高原的自然環境與農林牧業
}

\author{
婣 前 椿
}

(中央交委西藏工作隊)

西藏工作榢震業科悬組到西藏高原上去工作 了丽年多，考察了高原上的主要農區、林區和東 部的主要牧區, 並在拉限做了一年多的栽唔 試 瑜。現在把這次考察中所了解到西藏的農、林、 牧情况作一個節單的介稆。

\section{一 自然渨境}

西藏高原在地質史說來是相當新的，但因墨 正當强烈的海洋季風的吹拂，透緣部分和地翼楆 造上的斷裂地带，已經受到劇烈的冰雪侵刢和流 水侵玲, 而成了海找比較低的山嶺。在這些山嶺 的中很多焂河谷底部，是高原上海拔最低、最温 喛的地方，也是西藏高原上的主要岪區和林湂。 由於海洋來的水汽難以達到离原內部，因之降水 量小，和蒸發量抵消後，再没有很富裕的水分， 所以未能集成一婪流向海洋的河流。水聚流在低 的地方，而成內陸湖泊，這一片廣大的內陸水 系地區以及通问海洋的河流最上源部分和分水 顾, 是屬於牧區的範圍。

太陽輻射: 西藏高原的緯度相當於汇蘇和浙 江，高度都在海拔 3,000 公今以上。而絕大部分 地區在 4,000 公尺以上。一般說來高原上空氣稀 薄, 含微塵少、水汽少, 空氣的透明係數大, 而 太陽輻射中的短波光線受散射損失少。和六原比 䖝交, 原上的直接輻射强, 再加以日留時間長, 嵪原上的太陽能是可以考虑來更充分的利用的。

氣盕: 高原面皘很大, 南北約佔緯度 $7^{\circ}$, 東 西約佔經度 $15^{\circ}$ 。這樣廣大的地面來接受較强的 太陽輻射量, 和一孤找川峯的地面有很大的差異, 例如峨罣山頂在海拔 3,000 公尺大右, 已經很冷, 不能生長糧食作物, 而高原中部 4,000 公尺的地 方, 還有相當的温度, 來供青稞的生長成熟。
高原上的日較美大。日較差大的原因, 是由 於高原上所受太陽直接輻射比較强, 而夜間㬏射 散熱也比較快。而在較高的沁坡和!萃上，夜間 失熱得比河谷台地上快，因此使空氣温度降得很 低, 密度很大, 向下移動而成篇冷氣流, 下沉到 谷底, 使谷底的夜間低温降到更低。所以在昌都 的台地上, 日較差可以涬到 $29^{\circ} \mathrm{C}$ 。到了 4,000 公

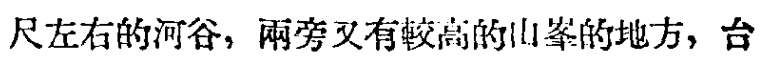
地上就容易遭受霜害。

從昌都、偭多、則拉宗和拉薩四個地方短期 的記錄來看，絕對最高温度只在 $30^{\circ} \mathrm{C}$ 左 右, 一 直保持在 $5-20^{\circ} \mathrm{C}$ 的有三、四個月, 這種低温的 環境對青稞、小麥的生银是有利的。

雨量: 高原上雨量的分俳主要是由水汽供給

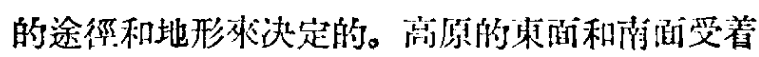

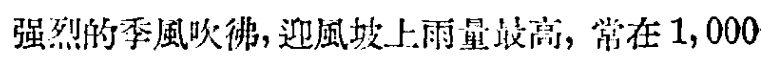
高米以上。喟種雨量較高的地方是生長森林的地 區。由於强烈的季風, 常常循着河谷來輸送水汽 到高原中心去，区之森林湢也能沿着幾條大的河 谷分倠到高原中心。每條河谷的雨量分倠和季風 所能達到的深度都有所不同, 這要看河谷的方向 和谷口的地形來决定的。例如雅魯藏布汇谷口正 對着强烈的西南季風，所以能使潮淑的季風深入 地吹到它的主支流上法。

在河谷下游由 3 月開始雨季, 越向上游雨季 開始得越掘, 到了拉落、日喀則, 雨季就延到 4 月底才開始，到 9 月就結束，而下满子的雨季叮以

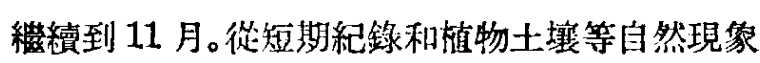
桃推测，平坮年雨量如下: 通麥在 1,000 毫米以

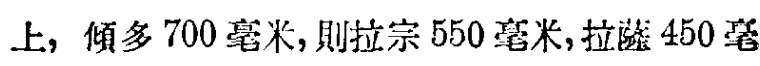
米左右, 日愘則就只在 400 毫米以下了。雨量由 下游向上游遞減。河谷中雨量集中在作物生長 


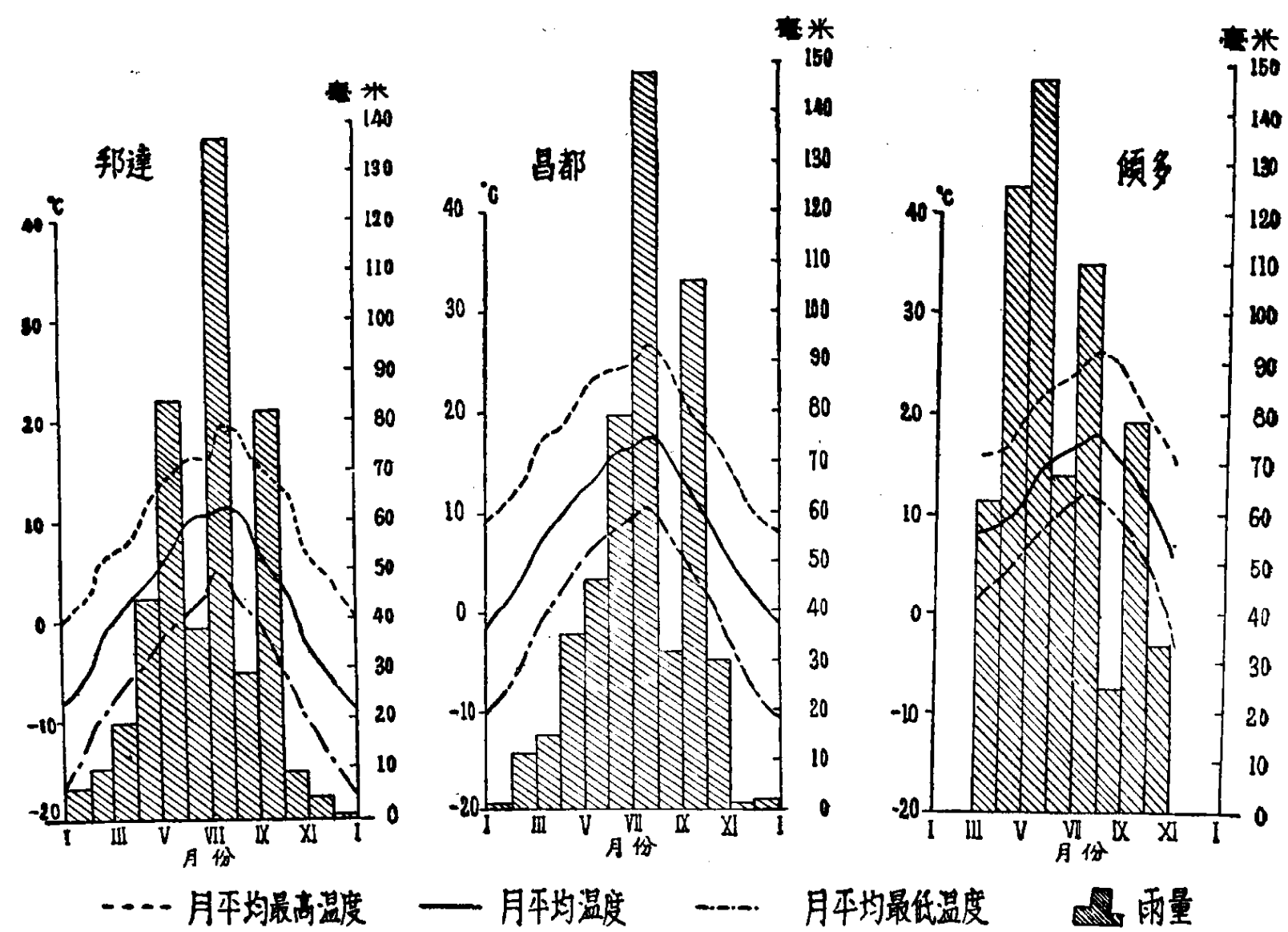

邦達、昌都、倾多三地1952年温度與雨量的記錄

季。河谷底部氣温高, 蒸發量大, 除了下游雨量 特多第比較潮濕的森林氣侯外, 其餘都屬於牛 乾早的草原氣候, 以絕大部分農區而論, 可以說 没有灌溉就没有農業。我們會經在拉萨做一储灌

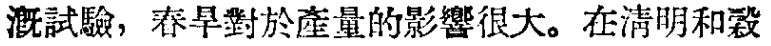
雨播種的青稞，少許灌水的地比不灌水的地要增 鏟四、五倍。

自然區域的劃分：由於高原上測候站、台既 少, 而氣候分倠情况文特别複雜, 所以氣候環境 的區劃, 主要的要從植物和土壤的分枋來着手, 由於這樣，在自然區域的命名上也是以植物篇 主。簡單的區劃如下。

$$
\text { 第一區一一寒漠及碱地區一一包括藏北㒸塘 }
$$
和藏南喜馬拉雅浽雨影部分, 高度都在拔海 4,500 公尺以上，雨量稀少，没有氣候記錄，根據旅行 的記載來估計，大部分地區降水量不會超 過 100 毫米，每天日較差很大，最大的日較差可以達到 $30^{\circ} \mathrm{C}$ 以上，冬季最低温度可以達到 $-40^{\circ} \mathrm{C}$ 左 右, 年本均温度在 $0^{\circ} \mathrm{C}$ 以下。在夏季常降冰電, 每年 9 月到次年 4 月是風季, 氣候乾燥寒泠, 地 勢高的地方是寒漠, 土壤生成綬慢, 有的還在冰
磧母質階段, 只能叫石砤地带, 生長一些地衣和

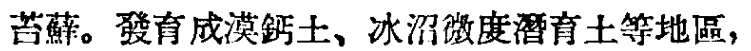
才有一些熱狀植物等, 這都是一些特別能酎寒耐 旱的植物。植物生長成坐塾狀, 主要是因篇熟狀 植物的容熱量大, 風吹不進去, 再加以浸種植物 所吸收的雨雪水, 能使之在坐熱下保存起來，所 以能適雄乾燥寒泠的環境。在較低洼的地方是監 碱沼澤和內陸湖，附近的土壤因水分充足，植物 比較茂盛, 特別是徼草屬 (Cobresia) 和篦:草屬 (Carex) 的草, 草根細密繁多, 相互交織而成 草皮詹，發育成草甸壏漬土。

第二區一一寒泠灌木草原區一包括各河流 的上游部分，還包括第一區邊緗上面 積小的內 陸水系, 海拔高度都在 4,000 公尺以上, 氣候方 面只有邦達一年的記錄 (見圖), 大致可以 推測! 這地區一般情况，年平均降水量 200-400 毫米; 絕對最低温度, 可以低到 $-30^{\circ} \mathrm{C}$ 左右, 最大日

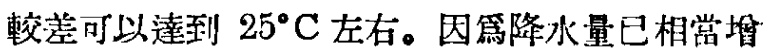
加, 而氣温低, 蒸發小, 所以地涌比較潮澗。但 冬季凍土期較長, 對植物來說, 生理乾旱期還是: 比較長的。在管草屬和㞺草屬的植被下地勢比較 


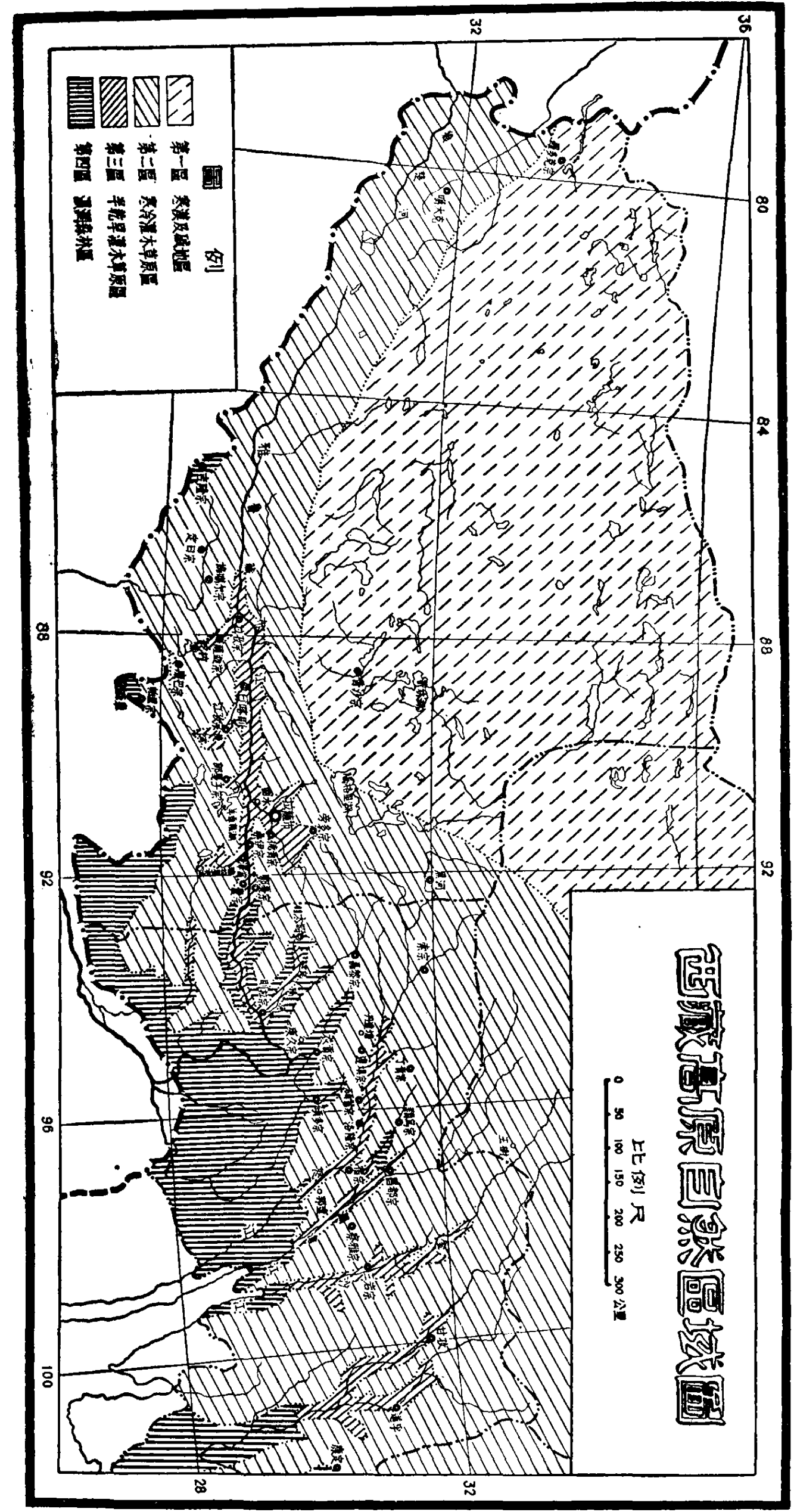


平緩的分水颛和冰川谷中，由於排水不良形成冰 沼挛育灰化土，有相當坡度排水良好的地方形成 生草潛育灰化土; 在陰坡上還生長一些酎寒的灌 木，像聚枝杜鵑 (Rhododendron fastigiatum) 和皮氏柳 (Salix biondiana Seem) 等。

第三區一一牛乾旱灌木草原區一一包括幾條 大河河谷地帶，以及少數濱湖地區。氣像記錄可 以以昌都第例 (見圖), 絕對最低温度在 $-20^{\circ} \mathrm{C}$ 以下，年平均降水量 300-500 毫米; 降水量高的 地方也是温度高、蒸發强盛的地方，結果地表一 切現像還是屬於牛乾旱氣候的範園。降冰需的機 會很少。

在河谷階地及䀝形地上形成的淡栗銔土是高 原上絕大部分祳田所在地，土翼由砂士到細砂壤 土，地面植物比較稀疏，只有西藏紫雲芙 (Astragalus tibetica Bth. ex Bak.)、白茅 (Peunisetum flaccidum Griesb) 等酎早的植物。在 河谷川垛上有較密的灌木生長的地方，士壤表土 含有機質稚多而形成栗鉆土; 有楊樹等偘木生長 的地方就形成森林棕銗土。

第四區一一濕閵森林區一一逪一區的主要特 點是氣候不太寒冷而地面水分充足，這裹衙又可 以按温䁔和潮㬎程度的不同而分成三個亚區。

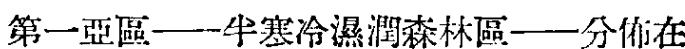

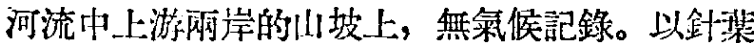
林䉆主，在海拢較高的地方間誰有一些灌木林， 陰坡是杜鹃和柳喍，陽坡是冷㭘和小萖，所發育 成的土壤，統稱棕色森林土。

第二亞區——温和潮潤森林區一一分佈在河 流中游的网岸山坡上，氣候有波密傾多不足一 年的㲹錄隶做代表（見圖），年平均温度 10$15^{\circ} \mathrm{C}$ ，絕對最低温度在 $-10^{\circ} \mathrm{C}$ 左右，年平均降 水量 600-1000 毫米。生長的喬木有雲南赤松 (Pinus yunnanensis Franch)，四川白樺 (Betula mandshuica var. Szetchuanica Rehd.)、 青棡（Quercus semicaprifolia Smith）等。 在它們的森林灰化作用下，土壤發育成灰化棕色 森林土。

第三亞區一一温暖潮濕森林區一一分佈在河 谷下游, 也就是在高原邊線下切最深、海拔最低 的河谷中。無氣候記錄，估計絕對最低温度不會 低過 $-15^{\circ} \mathrm{C}$, 年平均降水量在 1,000 毫米以上。
在造區生長的喬木有雲南落葉松 (Larix Griffithiana Carr.)、喜馬拉雅冷 杉 (Abies Webbiana Lindl)、徙皮樺 (Betula utilis D. Don) 等。在這些森林中, 灌木和草本植物很爲複雜, 在森林的灰化作用和生草化作用並立的情况下， 便生成了生草灰化土。

\section{二 掌㨡况}

豊區興作物的分佈: 西藏高原上的農區，紹 大部分是分你在河流的雨岸的台地和星形地以及 濱湖的地方。最主要的震煰是雅鲁藏布江中上游 區域，西自拉孜，東到則拉宗，中間包括䓇迦伂 湫、年楚河、香河、拉薩河、雅拉星布河（山南）、 尼陽河等支流河谷。

沿雅您藏布江主流河谷在拉孜到日喀則一段 中, 主要㖘田都分们在有支流灌溉的地方, 如通 梅、當拉、東嘎等; 有很多地方因篇還沟有引上 水, 而閒置在那裏。

尼陽河從太昭到則拉宗一段，以及波密地區 （波堆藏布江流域），雖然氣候湿暖，但是還有不 少荒地, 造些地區在農業發展上是很有前途的。

至於怒江、測洽江等河流的河谷，我們只穿 越了幾段，全面情况不甚了解。

在西藏地區，農民已經種植的作物種類（不 包括蔬荣）有青稞（瑧、秋播）、小麥（春、秋

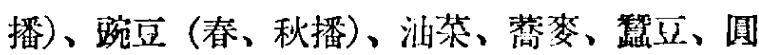
根 (即蕉莘)、馬鈴著、大踇、燕麥 (Avena

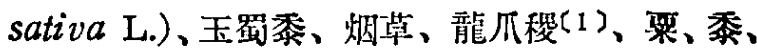

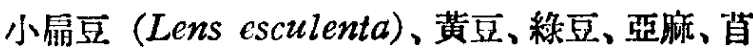

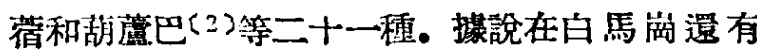
水稻和棉花。在數量上說，春青稞是厭倒一切的 作物，春小麥和踠豆次之，油茶、䖝豆、蕎麥和 圆根又次之, 餘则零星種植而已。蔬荣只有維萄 和拉薩白荣等。在拔海 4,300 公尺以上，青稞絊 乎是唯一的作物。

野燕麥 (Avena futua L.) 普通雜生在所有

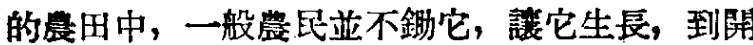
花、灌將時找掉或等到成熟特收割來做会司料。收 分枝。

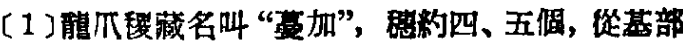

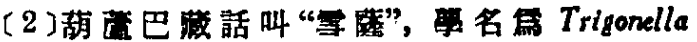
foenumgracum，是一年生的豆科牧草. 
䏛時, 稳上成熟的種子, 便掉落在地裹, 明年春 灌水地後, 刃㻐芽出土。從飼料生産上來 看, 野燕麥是一種牛裁培的鸰料作物。

西藏㖘區的作物及其分佈, 是答動人民在和 自然作网爭中，找到了自然環境的規律，根據逼 規律結合了自己的需要而得到的結果。目前西藏 漓原上盛行種植的作物種類如青棵、小麥、踠

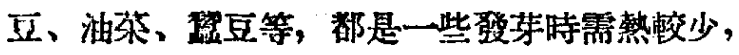
幼药期比較执寒，直到成熟期間只需要中等的温 庭的植物。例如青稞的分伤特别廣, 種植特别 多, 就是因霨它能够在一個經常低涼的温度下生 長, 量满, 生長期短, 播種期的彈性大, 道都 是青棵在適應高原環境中的有利條件。同時高原

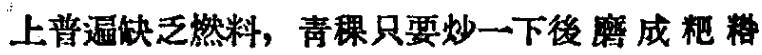

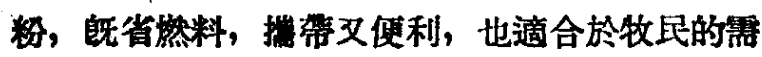

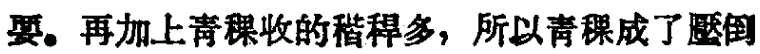
一切的稙食作物。

西藏高原上程大部分是一年一熟的春作區， 但是在工部和波滵地覆拔海 2,800 公尺以下的地 方，除了一年一熟的春作物外，還種有少量的冬 作物。冬作物中以冬青棵票主, 冬小麥較少。除 了波密的衣貢種了冬作物遠可以種一季秋, 一年 网熟外，其餘的地方收了冬作物或是再種一季圆 根，或是仍然一年一作。我們估计造些各作物的 抗塞性不合很强。

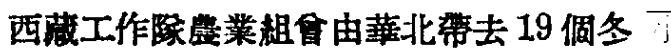
麥品種和 2 個冬黑麥品種, 於1952年10月底, 任

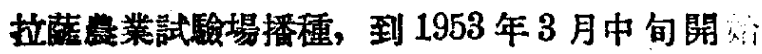
返青，5 月上旬大部拔穊，5月上中旬抽䖽，7月； 白開始收模，一直收到 8 月29日。踓然在整個 詥中, 田間管理比较粗放。但是從植株高度、 賟力和愁部形態等來看，試種的冬作物生長得 相賞良好的。冬小麥生長的高度都在 150 厘米 下，冬黑数生長滈達 200 厘米。根據小區座量的 推算，一般産量每站都在五六百斤上下，高的 七八百斤。而“彼特古斯 194” 冬黑娄則達 1,010 斤。各品種的種子品質比較本地春小麥第好, 个

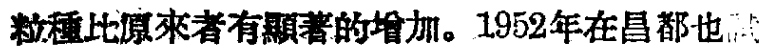
種西北冬小麥成功。選些事實說明冬作物從工部 控展到挂蒌和昌都一需是很有希望的。

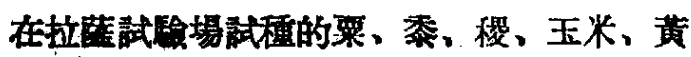

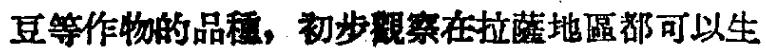

長並成熟。蔬荣方面, 通次在拉蒌試種成功的有

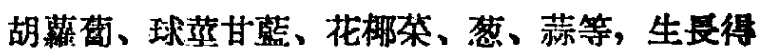
比平原地區還好。其他如南瓜、黄瓜、茠椀豆、 四季豆、清荣、瀋茄等也都生長很好。甚至一般

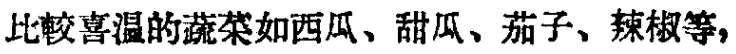
在露地也都能生長。

耕作䑦况; 西藏高原的農區, 踓然包括了相 常不同的海拔高度、地形、氣候、土壤和其他的珢 境條件，但耕種方法，基本上是差不多的。一般 說來，耕作相當粗放，這是因篇帝國主義的工莱 品鐱入西藏以後, 各地的煉銭㠊紛紛倒閒了(1), 所以農民使用鐵睤農具一天一天減少，耕作也就 粗放，甚至有些耕地也荒䇼了。但逪並不等 於 說, 藏族勞動人民的農業生產技術是很落後的, 相反地, 他們在興高原的羪苦的自然環境做頑强 网爭的過程中, 確是積累了不少的竇贵經驗。在 迨一大極其短促而粗略的調查中，我們就看到一些 合乎科學原則的耕作方法。當然從整储耕作情况 說來，有待改進和提高之處還是很多。現將沿途 調查了解的耕作情况，分别介紹如下:

1.輪作制度一一西藏高原上主要農區都可以 說有一套輪作或休間的制度。一般把踠至和青稞 來輪作，這至少說明藏族農民已經認識到豆科作 物和禾本科作物交互輪種的好處。

蜦作制在各地區不同，輪作年限自 3 年到 5

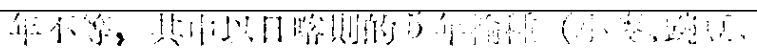

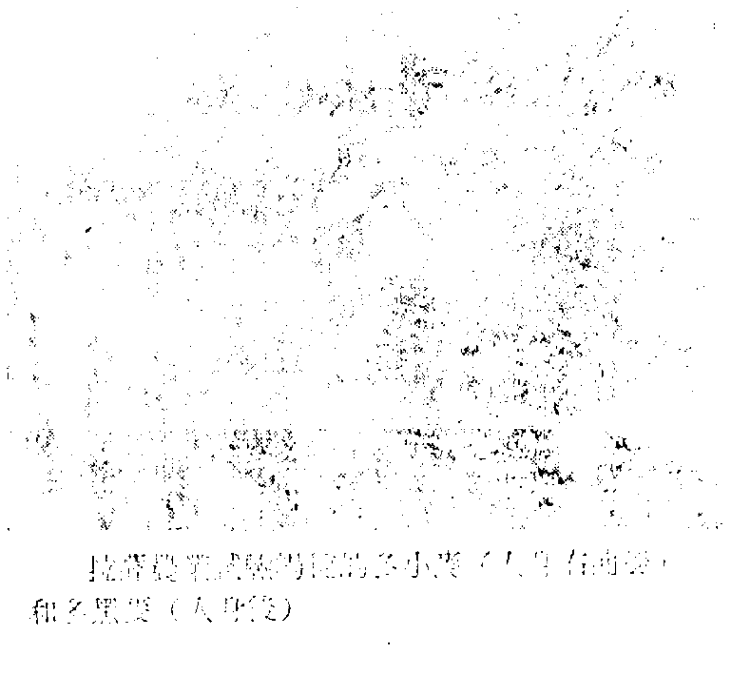

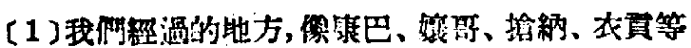

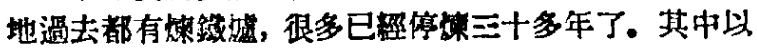
衣實停妵較渥, 也有 18 年了。 
青稞、休閣、葫蔏巴）最篇完善，值得推廣。

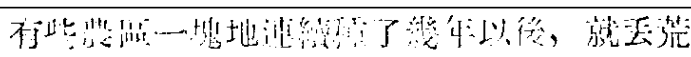

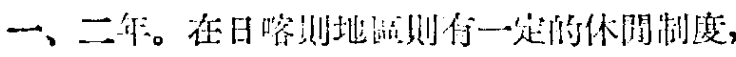
Istotis

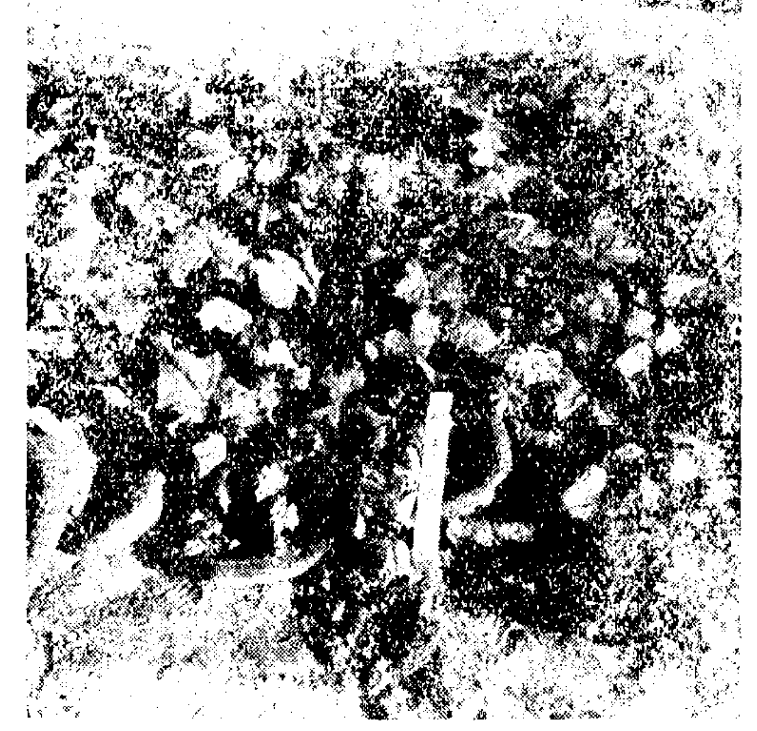

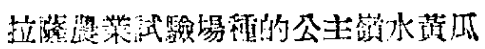

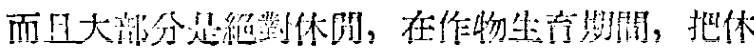
閏地犁上三、五次, 多的可以澾到九，十次，迢 就炤顧到了中耕除草和籍土蓄水的作用。有的地 方, 在休耕地上還灌上网三次水, 很好地蓄積水 分，以抗明年春季播種時的乾旱。

西藏高原上的農地多是混作的, 青稞地亳常 常可以看到小麥、畹豆、油荣等。後藏地區踠豆 和油荣很少單獨裁培的, 都是和青稞、小麥混裁。

2. 整地一一西藏農民耕地都用“二牛拾槙式” (如圖)，太昭以東的地區還有把犁軽前端所栓附 的㮖木槓, 勆在牛角上, 使得牛的行動緩慢。在 太昭以東的地咞都是把䫅子架在雨頭牛頙上。耕 犁都是水的，很少地方能在前端裝上一個鐵質犁! 銓。有些地方踓有鐵筫犁鏵, 但没有犁鏡, 因此 仍不能翻土。那種木犁入土的梁度和宽度都只尘: 3 寸左右, 因此黎地的結果不過是檠動一下土: 面。好在西藏耕地的土壤除了江孜附近比較粘一 些以外, 都帶砂性, 棃耕容易, 譄種鯬具也能拀 强對付。但是爲了增加產量, 必須改良錅具, 浽 能够翻土的鐵黎鏵，提售深耕。

春耕後耙地的很少, 在拉蒌河谷和後藏地酒

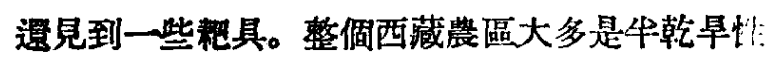
的氣候, 但是除了休閒以外, 很少有減少土嫶等 䅧以保持土㙲水分的操作。

3. 播種一一點播或穴播的情形很少，一般都
是撒播。棃地後先在地面上稀稀的撒一次種子,

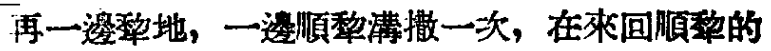
操作中也就附帶進行了輹土的工作。

播種期的早晚當然要因各地的氣候情况來决 定, 不過有一個普掘的現象, 就是播種期拖得很 長, 播種量也較多。青稞、小麥每敬播種量總在 25 - 30 斤之間。青稞的播程早的在 2-3月, 掘 的在5一6月。收檴一般用鏡刀, 倜别地煰（如工 㰾) 有用网根竹片或本棍夾取麥徳的。

4. 田間管理一一由於撒播, 中耕鋤草只能在 纤苗泪罢行, 因此一般的地裹雜草很多。在作物 生育後期也有找野燕麥和其他雜草, 作篇牲苗饲 料的。第了中耕䥞草方便, 應該逐步推行條播。

肥料缺乏是西藏農業生鉾上普漏存在的一储 問題。一般藏胞不施用人蒵, 而牛馬炎又全做燃 料燒了。所以有些農地就不能上肥, 佟件好的每 沟也只能施上幾百厅的草篹肥而已。因此, 目前 除了㤫該推行輪作制和絕對休阙以㙁加肥力外，

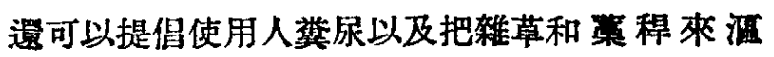
薮。此外, 設法把䔉柴問題解决, 就可以把級大 部分的牛馬菼用到農業生産上去。

在絕大部分豊區是牛乾旱氣候的情形下， 田水利是農業生產的先决條件。藏族鹿民對一般 作物的灌溉時期, 大致掌挃了農作物墢育的基本

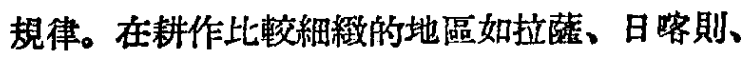
濢當等地, 有些畦做得很小很整齊, 從做畦的工作 中就可以看到藏族農民對於灌溉是十分重親的。 但是因第受工具和器材的限制, 一遇到石方工 程, 就産生引水的困難。興修小型水利, 也是㤝

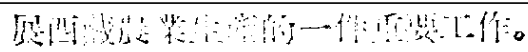

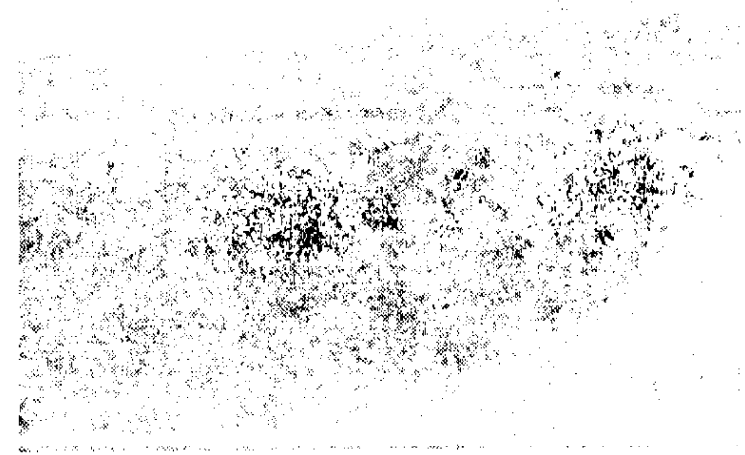

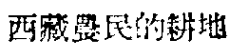


開於嫁客方面，以麥類的黑穂病和銹病較篇

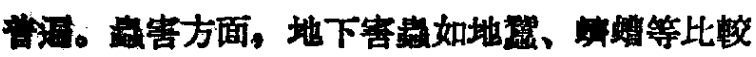
常見。

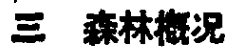

近工作中，棵林調查做得很少，僅能作一 棈括的介紹:

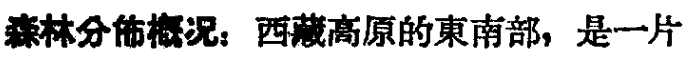
廣大的森林，和要南的森林相銜接。這次所考察 了解的林林可以分算三大踽: 一是河谷上游森林 亚，包括雅鲁茞布江及其支流和怒江、澗滄江、 金沙江的中上游，遗睃因篇河谷的下切，使樹枝 状的流域系統中，能有一個不太寒冷的環境，來 㑣林生長。二是雅智藏布江中游林區，氣候比 交温和悬潤。三是喜馬拉雅山南麓林區，包括南 却巴華萃以南的藏布江下游地品, 在三個林區中

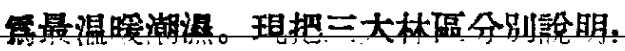

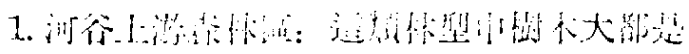

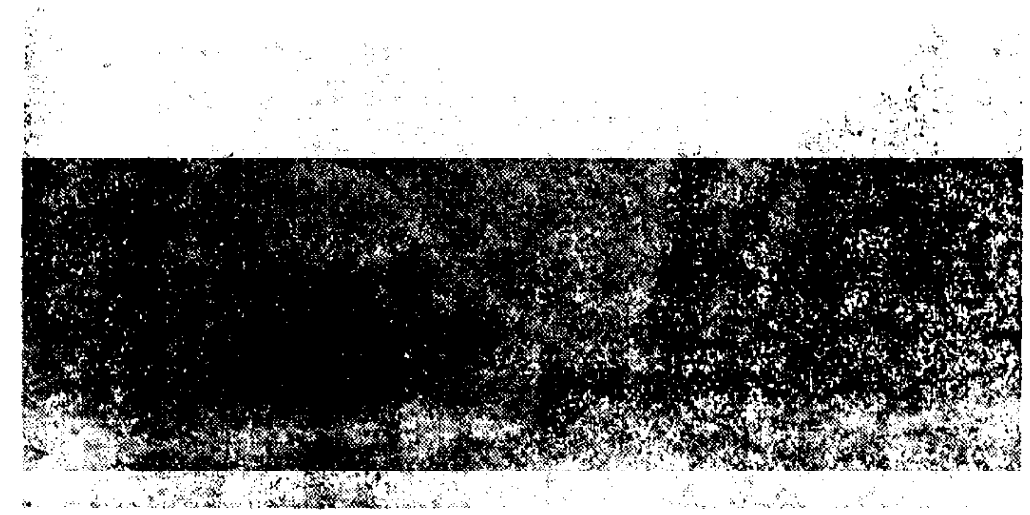

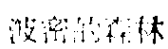

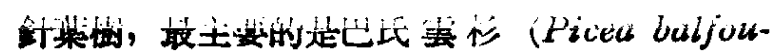
riana Rehkd. et Wits.), 分协可到拔海 4,250 公尺。其次有潾皮冾杉 (Aibes Squamata Mast) 和榮果蛋柇 (Picea purpurea Mast.)。以上三 理樹都是除性樹，在陽坡上是冷檜的純林。濶柋 楼在逼林區內有兩種此较重要的，就是们川白樺 和山楊。

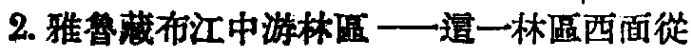
宗酳始，東面和雲南的林區相聯接，南面就是 毦王、白馬峝、察隅的地界。樹木有雲南赤松、 四川白㩲、青悯、紫果雲杉、咅馬拉雅冷杉、華
山松 (Pinus armandii Franch) 和雲南落集 松等。

3. 意馬拉雅山南麓林區一一道一個林區包括 亞東、日阿（在羊卓维湖之南）、羅玉、白馬厥、 祭阳等地區，我們只到過亞東。拔海 2,900 以上 是針葉濶集混交林帶，針葉樹有喜馬拉雅终杉、 喜馬拉雅圆柏和雲南落葉松等, 潤葉樹方面有㮸 皮櫵等。2,900 公尺以下的林帶是润柴林带，樹種

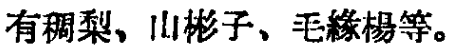

森林現況: 河谷上游的森林區, 在森林區中 是比較乾旱寒冾的。一經斫伐, 林木更新就比較 困難, 有一些森林已經草原化, 或者有草原化的 䞨勢。其他兩個林區氣候條件有利於森林的自然 更新, 並且人霨的破壤也比較少, 常是綿延不斷 的森林，一般的針葉樹很多高達40餘公尺，值徑 1公尺以上。但是有不少的過龄樹木, 倒卧林中,

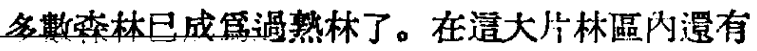

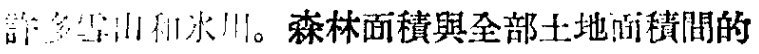

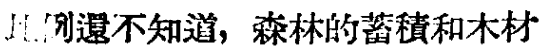
池不清楚。但是無論從樹種來看, 下材量來看, 肯定的這都是一片 的害䔰的林區。

當前最重要的問題是在防止森 扷焱，我們在途中就遇到次 因斫柴、行䱂時生火而引起的火 多。有一次燒了三天三夜, 值到我 們襍開那地方猶未焻減。有些地方 的笨林受寄生植物如松蘿和一種 科待生植物的侵害, 而有成片死亡 $\mathrm{H}^{3}$ 。

森林则库：巴氏雲杉樹皮，曾

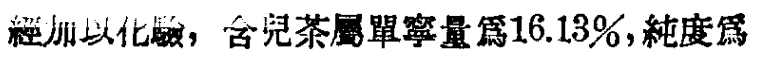
$47.77 \%$, 巳在一般標淮以上。在發展西藏製革工 業上就可利用它來慗造拷膠。

森林中出产的査材初步統計約有 300 狳種。 同時有很多珍貴的毛皮獸如水獭、猞猁等。野生 果樹也很多，如桃、杏、樱桃，將來都可能成篇 好的砧木。

\section{四 畜牧概况}

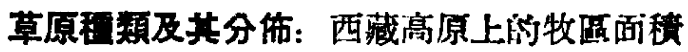
潦蕳，一般高度都在拔海 3,800 公尺以上。西花 
高原的自然草原中，以莎草科的营草屬、㟶草屬 及禾㶱科的旸茅屬 (Stipa) 等幾種草原植物篇 主。由於環境炛件的不同，高原西部以管草草原

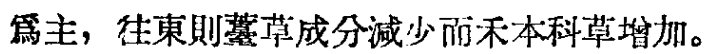

巍草類是特别喜歡潮濕的植物, 生長的地方 都是排水不良的低空部分。禽草類一般高度在 30 厘米以上, 在藏北高原, 可以高達 45-60 厘米。 但含糡維質多, 不易消化, 只在開花以前, 牲畜 食其稍部; 在開花以後, 維質增加, 適口性低, 所以秋後還有大批殘草。到了真正缺草的季節, 牲畜才又回來啃它。

整草類是生在稍乾燥的地方, 植株的平均高 度約10-20厘米，產草量低，但營養價值高; 同 時春季發芽早, 3-4月間已現黃緗色, 最先解决 青草問題, 但在 9-10 月就成了枯草。壹草在稍 濕潤的地方較密。在乾燥環境下, 生長稀疏, 細 如牛毛, 每本方公尺産草量僅 150-250 克。

在藏北, 嚄草草原約佔全部草原的 $2 / 3$, 而 耑草區約佔 7-10\%。鹤草草原大致第純牧區及 重要牧區所在地, 這類草地, 羊能利用的牧草達 $60 \%$ 左右, 並且牦牛也能利用這類短草。只有馬 不適於短草, 則零星牧於有高草的地方。

莎草禾草混生草原分㛂在高原東部降水量較 多的地方。遭些植物植株較高較密, 產草量也較 高。

混生草原的分仿，西自索宗以東，北到玉 樹, 東到装謶, 南泊則因受河谷切割, 與森林和 灌木林相間。薄原由西向東, 管草屬植物逐潮減 少, 到雅龍汇流域有變篇禾本科草原的情况。這 些地區濕潤的川坡上已能生成高草類型, 可以割 草。在康藏尚原兆說, 這是放牧和割草都可以進 行的俊经草原, 對馬、牛、羊的牧放都有條件。 所以除牛、羊以外, 這些地區還有玉樹和和西康 馬等優隐熙種。

牧戈在各季節內也探取輪換放牧, 但並不是 有計劃的顺序前進, 這樣踓也可以使草原得到休 息, 但牧草不能按時恢復生長, 因此草原有過度 利用的情形。若能合理管理草原, 就可以增加载 畜量。

家畜種類及其性能：西藏高原上的家畜以牦 牛和綿羊第主, 黃牛及蝙牛霨農區主要牲畜。農

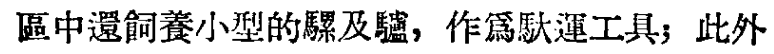

還養一些山羊、邹、豬等。馬踓是主要交通工具 之一, 但數量不多。

牛牛是高而乾寒地帶特有的牲音, 在高原上 分版很廣, 特牛的特點是能走峻險的山路, 能在 冰雪中行進, 又能浮游過河, 再加以能敌食短龺, 䮦運六、七小時後, 在短草地.上放牧一夜, 就可 以恢復體力, 所以它是高原上的主要運輸力量。 此外, 在農區還有用它來耕田和踩場脫粒的。钝 牛產奶能力没有精確數字統計，大致泌乳期5-6 個月, 每日產乳 2-3 斤, 含脂率較高, 一次泌 乳期可以產酥油 15-24 斤。牦牛肉是费牧區的主 要肉食; 牦牛的汇一年可以前一次，每頭能產毛 2 斤左右, 可以織帳棚及雨具等; 牛皮可等革; 牛尾輸往國外。單單牦牛一項就解决了藏族牧民 衣食住行的主要問題。

牦牛的繁殖率很低, 普通兩年產一㸿, 箱殖 率約雼 50\%，牛犢的死亡率亦澾 50\% 左右，牛拿

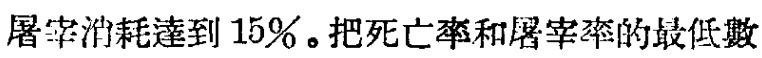
字來估計，增殖率也不會超過 $1 / 10$ 。根據這數字

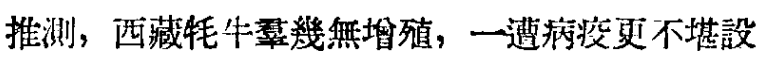
想。篇了要塯殖牛翌, 首先必須堆加母牛的繁殖 率和隇少㸽牛的死亡率。這些要從改良鸰養條件 及防止病疫着手。

犏牛䉆託牛與黃牛的雜種, 以公黄牛和母枆 牛交配的第多, 產生的犏牛體大能酎寒, 性制良 而力大, 主要是供農區犁时和䭾運之用。犏牛每 日遮乳量可達 3.5-4 斤。在一個泌乳期 7 個月中 可製酰油 35 斤左右。黃牛在農區主要是供 乳 用, 乳用黄牛常佔農區牛數牛數以上。

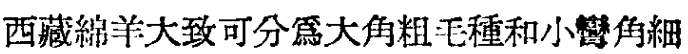
毛種。大角粗毛羊主要分㛂在藏北牧區，伯長而

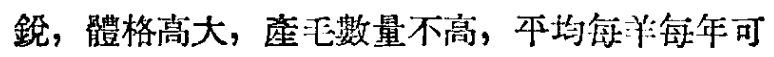
剪 1.5 斤羊毛。藏北監湖的監有很多是由方䭾運 到農區去的, 每隻羊可以䭾二十多厅, 沿途牧放, 也不卸载。綿羊也是牧區一支運輸力量。

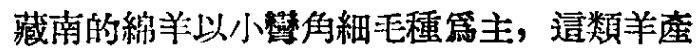
毛較多, 一般每年產正 2 斤, 最高達 5 斤, 羊毛 紡紗細度一般都在 50 支以上, 最細能達到 60 支, 含油脂 $5-13 \%$, 可以說是很好的羊毛。缺點就是 毛色太雜。在藏南, 綿羊還擠奶, 來提跮酥油。

家畜飼羡管理與病疫情况: 藏族牧昆在利用 天然牧場和馿服牛牛上是有很多好辦法的, 一個 
牧民能牧放戨頍牦牛, 在運輸時也能照料十頍 左右。就是枆牛㡎了野性, 他們把牛篹瓷在口鼻 上, 就能使它安靜下來。

枆牛是西藏高原原产, 它的㷒化也是藏族答 别人地的貢獻。

在牧區的綿羊和枆牛完全是靠天然牧草隶稂 活的, 農區的役畜在工作忙時, 才喂一些青棵稭 程, 農閒時就在草地和田間放牧, 只有乳牛才喂 一些精料。䭾運牲畜在負重行遠時才喂料。無諭 牧画和農區, 初生的犈牛在 5一-10 天內全喂奶, 以 後就逐漸喂脂乳或脫脂乳和粭粑, 所以幼畜一般 都謪育不良, 死亡本高。在若千牧區是可以種植 牧草的, 所以除了草原的合理利用外, 種植牧草

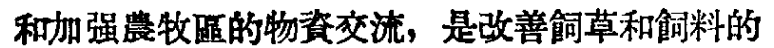
途徑。

西藏剪毛工具是一把小刀，或是不用小刀而 用手撕。剪下的毛既不整齊，又把羊弄得㴜體鳞

伤。所以剪毛工具的改善是很需要的。

關於病疾情况，傳染病有牛瘟、牛羊口蹄疫 和牛傳染性的胸膜脯炎。連三種病經常㡎生，墢 生後能引起大批的死亡, 藏族牧民對於牛盒及牛 傳染性胸膜肺炎有一些免疫預防的方法。對於牛 監探新酎過的牛的血來灌健康的牛, 使健康的牛 也墢病耐過，酎過的牛可以終身免疫。造種簡單 有效的辦法，在西藏高原上對防止牛㿎是起了一 定的作用的。牛傳染性胸膜肺炎色疫法, 則不如 牛㨕免疫法的有效。對一些寄生蟲病和有些普通 的病，由於西藏醫樂的缺乏，還没有什呩有效的 辫法。

西藏和平解放後，在昌都成立了哭器院院，在 拉限、江改、日喀則、黑河、曲水、帕黑、丁青 等地先後成立了家畜門診所, 已經開展了家音普 通病的治潦工作，並在覃采中得到良好的反胦。

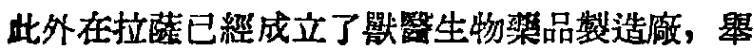

辦了鄂疫防治人員訓練班，第今後工作的開展淮 備了條件。

畜産加工利用情况: 孚品的加工主要是提取 酷测（酸乳酪），酥油是西藏最普遍喜要的食物，

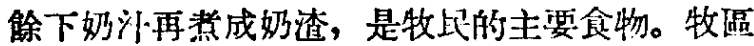
的粗差毛，大多數外銷。藏南的牛細羊: 正，多数

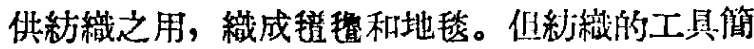
單，需要改良。此外，西藏的牛羊皮很多，仃以 舉辦製革工業。對牦牛星、猪悲、腸衣等外輸的 貨品，虑該注意質量的提高。畜痤品能得到合理 的加工利用以後, 牧民的生産可以大大提高, 牧 民的生活也可以大大改善。

$$
\times \quad x
$$

總括起來講，西藏高原的自然環境，對譨、 林、牧生產的發展，提供了一般㖞原少有的有利

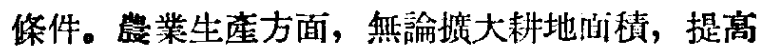
單位面皘应量, 種植新的作物種類與品種, 都是 很有發屡前途的。如在現在的基礎上，農具稍加 改良，提高耕作技術，肥料和水利作適 當的解 决，單位的積应量都會有㙷著的提高。

西藏高原的森林區，以面皘來論，僅次於東 北。雖然因篇交通運輸條件的關係，大量的開墢 利用，還要等一些時日，不過護林和调查工作隼 該及早着手進行, 將來有着無限的利用能辽。

音牧業方面，有更多的牲蓄可以繁殖们㿥， 經濟意義大的牦牛和牛細毛的綿羊，都適於就原

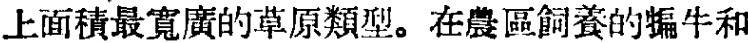
黃牛（拜牛）以及高草地的馬匹，都可以從防止

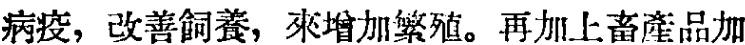
工利用的改良，就可以把西藏率原者牧生產问前 大大的推進一步。

我們在西藏高原上兩年來的考察和試驗的結 果，認第西藏高原的㖘、林、牧業的前途是無限 寬廣的。 